\title{
Disease Diagnosis Expert System At Chili Plants Using Bayes Method
}

\author{
Sri Susanti ${ }^{1}$, Olven Manahan ${ }^{2}$ \\ 1.2 Engineering Informatics Program, STMIK Pelita Nusantara Medan, Jl. Iskandar Muda 1 \\ Medan, North Sumatra 20154, Indonesia \\ E-mail: Srisusanti2305@gmail.com
}

\begin{abstract}
The state of Indonesian is a country with a large part of the population earning a leaving in the agricultural sector, the agricultural sector in Indonesian contributis quite a lot in the development of long-term economic development. The role of the agricultural sector is as a source of producing basic foodstuffs, clothing and shalter, providing employment, and contributing to high national income. Chile is one of the agricultural commodities that are needed in daily life, Because this commodity has many benefits. Often Farmers detect disease that is wrong. To detect disease in precisely requires expert or expert in agriculture. The number of expert agricultural expert can not Overcome the problem of chili farmers, so it is needed a system where the system can help the work of an expert. In the expert system Dease In These chili diagnosing plant identifications using Bayes method in process. This expert system is implemented $a$ in the form of a website the which aims to Facilitate access and use.
\end{abstract}

Keywords: Expert system, chili plant disease diagnosis

\section{Introduction}

Pepper is one of the agricultural commodities are in need in their daily lives, as this commodity has many benefits. Besides its use for seasoning pepper plant also contains kapsaikin, vitamin A, vitamin C, and antioxidants that are beneficial to increase endurance, melncarkan blood circulation, lower cholesterol levels and help the digestive process.

Some of the problems in the control of diseases and pests, among others, are the first signs that are not clearly visible so that farmers and the public is difficult to detect pests and diseases that attack plants and identification of pests or diseases that damage the plants must be quick and precise, if the identification and handling slow the damage the plant will be heavier so it would be fatal to the plant itself as well as the environment.

The expert system is a tool for diagnosing disease aroused pepper and assist healthcare practitioners to make clinical decisions intelligently. The results of the study may provide an effective treatment, and also helps to reduce the cost of treatment. Bayes Theorem is used as a decision-making tool to renew the confidence level of the information.

\section{Theory}

\subsection{Expert system}

The expert system is a system that tried to adopt human knowledge into a computer so that the computer can resolving the problem as was done by experts. Expert systems are typically used to perform interpretation and analysis, diagnosis, and assist decision-making (Oktaviani, 2012).

\subsection{Bayesian methods}

Bayes method is the method used to calculate the probability of occurrence of an event based on the effect derived from the observation of things. In this study, Bayes method is implemented to diagnose the disease and help in daily chilli many problems that can not be modeled completely and consistently. A reasoning where the addition of a new fact resulted in some inconsistency, with the characteristic features as follows:

a) The uncertainty.

b) The change in knowledge.

c) The addition of new faktu can change the conclusions that have been formed.

To address the issue of uncertainty, it can use statistical reasoning. Bayesian theory is used as a decisionmaking tool to renew the confidence level of the information. This method is applied to things - things pertaining to diagnosis were statistically associated with the probabilistic and the possibility of disease and symptoms related symptoms.
$\mathrm{P}(\mathrm{H} \backslash \mathrm{E})=$
$P(E \backslash H) * P(H)$
$P(E)$

$\mathrm{P}(\mathrm{H} \mid \mathrm{E})=$ The probability of the hypothesis $\mathrm{H}$ is true if given evidence $\mathrm{E}$. 
$\mathrm{P}(\mathrm{E} \mid \mathrm{H})=$ The probability of the emergence of evidence $\mathrm{E}$, jikadiketahui hypothesis $\mathrm{H}$ is true.

$\mathrm{P}(\mathrm{H}) \quad=$ The probability of the hypothesis $\mathrm{H}$ (according to previous results) without regard to any evidence.

$\mathrm{P}(\mathrm{E}) \quad=$ Probability of evidence E.

There are also steps in applying Bayes Method in expert systems are:

a. Inputting the symptoms that are known by the user, and then search for universal values by summing the probability of each of the symptoms experienced, or may be formulated by the following formula: ${ }_{i=1}^{n}=\mathrm{P}(\mathrm{E} \mid \mathrm{H} 1)+\mathrm{P}(\mathrm{E} \mid \mathrm{H} 2)++\mathrm{P}(\mathrm{E} \mid \mathrm{Hn})$

b. Having in mind the sum of the above, and then calculating the probability of the hypothesis $\mathrm{H}$ value regardless of symptoms / whatever evidence is as follows:

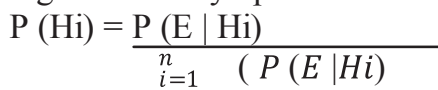

c. After knowing the results of $\mathrm{P}(\mathrm{Hi})$ or the probability of the hypothesis regardless of any symptoms, then the next step is menhitung evidence probability value $\mathrm{E}$ with the following formula:

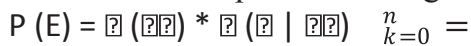

d. After obtaining the value of the probability of the evidence E, then the next step is to calculate the value of Bayes each hypothesis with the following formula:

$$
\mathrm{P}(\mathrm{Hi} \mid \mathrm{E})=\mathrm{P} \frac{(\mathrm{E} \mid \mathrm{Hi}) * \mathrm{P}(\mathrm{Hi})}{\mathrm{P}(\mathrm{E})}
$$

e. After getting all the value of $\mathrm{P}(\mathrm{Hi} \mid \mathrm{E})$, then the next step is to calculate the total value of Bayes with the following formula:

${ }_{n=1}^{n} \quad$ Bayes $i=$ Bayes $1+$ Bayes $2+$ Bayes $n$

f. And the last step is to calculate the percentage of the total value of Bayes with the following formula: Percentage $=1 \quad i_{i=1}^{n}=$ Bayes $i * 100 \%$

\section{Analysis And Design}

\subsection{Analysis Bayes Method}

The methods used in diagnosing diseases in pepper is Bayesian methods. Bayesian method is a method of the uncertainty for the design of the system that will be used to implement the results of diagnosing the disease in pepper berdasrakan symptoms are already in the analysis of disease chili.

\section{Table 1}

Symptoms Base Chilli Plants

\begin{tabular}{llc}
\hline Code & \multicolumn{1}{c}{ Disease symptoms } & Weight \\
\hline G001 & Children's bones yellowing leaves & 0,004 \\
G002 & Spotting become soft & 0.007 \\
G003 & Wrinkles and dries fruit & 0,003 \\
G004 & Skin color of fruit such as straw & 0,015 \\
G005 & The color of the leaves turned yellow bone & 0,006 \\
G006 & Plants grow dwarf & 0.009 \\
G007 & Smaller leaves and bright yellow & 0,005 \\
G008 & The leaves turn yellow then expands and autumn & 0.02 \\
G009 & Bottom leaves begin to wilt & 0.01 \\
G010 & Root and base of the brown bars & 0,014 \\
G011 & Fruit production declined and over time unfruitful & 0,008 \\
G012 & plants die & 0,018 \\
G013 & Blackish brown spots on the fruit surface & 0,011 \\
G014 & There is a collection of black dots & 0,012 \\
G015 & Leaves the bone thickens and leaves roll upward & 0,013 \\
\hline
\end{tabular}

Table 2

Symptoms Weight Value Chili Plant

\begin{tabular}{ccccc}
\hline Code & P01 & P02 & P03 & P04 \\
\hline G01 & 1 & 0 & 0 & 0 \\
G02 & 1 & 0 & 0 & 0 \\
G03 & 1 & 0 & 0 & 0 \\
G04 & 0 & 1 & 0 & 0 \\
\hline
\end{tabular}




\begin{tabular}{ccccc}
\hline Code & P01 & P02 & P03 & P04 \\
\hline G05 & 0 & 1 & 0 & 0 \\
G06 & 0 & 1 & 0 & 0 \\
G07 & 0 & 0 & 1 & 0 \\
G08 & 0 & 0 & 1 & 0 \\
G09 & 0 & 0 & 1 & 0 \\
G10 & 0 & 0 & 0 & 1 \\
G11 & 0 & 0 & 0 & 1 \\
G12 & 0 & 0 & 0 & 1 \\
G13 & 1 & 0 & 0 & 0 \\
G14 & 0 & 1 & 0 & 0 \\
G15 & 0 & 0 & 1 & 0 \\
\hline
\end{tabular}

In a case in the Office of Food Security and Agriculture researchers perform diagnostics against farmers who suffer from symptoms of chili, farmers are experiencing some symptoms of chili, among others: IF anthracnose fruit rot (Collectrotichun gloeospoiroides)

AND Yellow Virus (Gemini virus)

AND leaf spot (Cercospora Sp)

AND Fusarium Wilt (Fusarium oxysporum f.Sp)

THEN Experiencing symptoms of chili

Table 3

Symptoms Data Table

\begin{tabular}{|c|c|c|}
\hline $\begin{array}{l}\text { rule } \\
\text { Base }\end{array}$ & symptom & The type of disease \\
\hline & Kids IF bone yellowed leaves Is True & \multirow{6}{*}{$\begin{array}{c}\text { Fruit rot Antraknosa } \\
\text { (Collectrotichun } \\
\text { gloeospoiroides) }\end{array}$} \\
\hline \multirow{5}{*}{ rule 1} & AND Spotting become soft Is True & \\
\hline & AND Fruit wrinkles and dries Is True & \\
\hline & AND blackish brown patches on the surface of fruits Is True & \\
\hline & THEN Rotten Fruitanthracnose & \\
\hline & IF skin color of fruit such as straw Is True & \\
\hline \multirow{5}{*}{ rule 2} & AND Color leaves turn yellow bone Is True & \multirow{5}{*}{$\begin{array}{l}\text { Yellow Virus } \\
\text { (Gemini Virus) }\end{array}$} \\
\hline & AND Plant stunting Is True & \\
\hline & AND There is a collection of black dots Is True & \\
\hline & THEN Yellow Virus / Virus Gemini & \\
\hline & IF leaves and bright yellow tapers Is True & \\
\hline \multirow{5}{*}{ rule 3} & AND leaves turn yellow and then extended and fall Is True & \multirow{5}{*}{$\begin{array}{l}\text { Leaf spotting } \\
\text { (Cercospora Sp) }\end{array}$} \\
\hline & AND leaves the bottom began to wilt Is True & \\
\hline & AND Bone thickened leaves and leaf curl upwards Is True & \\
\hline & Spotting THEN Leaves & \\
\hline & IF root tissue and stem brown Is True & \\
\hline \multirow{3}{*}{ rule 4} & AND fruit production declines and gradually unfruitful Is True & Fusarium wilt \\
\hline & AND Plants die Is True & (Fusarium \\
\hline & THEN Fusarium wilt & oxysporum f.sp) \\
\hline
\end{tabular}

\section{Others, such studies Chili Plant}

G004 symptoms probability value $=0.015=\mathrm{P}(\mathrm{E} \mid \mathrm{H} 1), \mathrm{G} 008=0.02 \mathrm{P}(\mathrm{E} \mid \mathrm{H} 2), \mathrm{G} 015=0.013 \mathrm{P}(\mathrm{E} \mid \mathrm{H} 3)$ completion:

G004 symptoms probability value $=0.015=\mathrm{P}(\mathrm{E} \mid \mathrm{H} 4), \mathrm{G} 008=0.02 \mathrm{P}(\mathrm{E} \mid \mathrm{H} 8), \mathrm{G} 015=0.013 \mathrm{P}(\mathrm{E} \mid \mathrm{H} 15)$. completion:

1) Determining the value of probability:

a) $\mathrm{P} 002=$ Virus Yellow $\mathrm{G} 004=\mathrm{P}(\mathrm{E} \mid \mathrm{H} 4)=0,015$

b) $\mathrm{P} 003=$ Spotting Leaves

$\mathrm{G} 008=\mathrm{P}(\mathrm{E} \mid \mathrm{H} 8)=0.02$

$\mathrm{G} 015=\mathrm{P}(\mathrm{E} \mid \mathrm{H} 15)=0,013$

2) Determining the value of the universe:

a) P002 $=$ Virus Yellow

$\mathrm{G} 004=\mathrm{P}(\mathrm{E} \mid \mathrm{H} 4)=0,015$

$$
=0015
$$

b) $\mathrm{P} 003=$ Spotting Leaves

$\mathrm{G} 008=\mathrm{P}(\mathrm{E} \mid \mathrm{H} 8)=0.02$

$\mathrm{G} 015=\mathrm{P}(\mathrm{E} \mid \mathrm{H} 15)=0,013$ 